\title{
Az egészségfejlesztés emberi tőkére gyakorolt munkaerő-piaci hatásai
}

\section{Labor Market Effects of Health Promotion on Human Capital}

\section{P. GOTTFRIED}

Debreceni Egyetem, Gazdaságtudományi Kar, Vezetés- és Szervezéstudományi Intézet, Emberi Erőforrás Menedzsment Tanszék, gottfried.peter@econ.unideb.hu

Absztrakt. Napjainkban egyre nagyobb mértékben van jelen a munkahelyi egészségfejlesztés, hazánkban és nemzetközi viszonylatban is. A kutatásomban szakirodalmi elemzés segítéségével arra kerestem a választ, hogy a munkahelyi egészségfejlesztô programok, azon belül pedig a fizikai aktivitás hogyan befolyásolja a munkavállalók keresőképességét, valamint a termelékenységet. A termelékenység esetében jelentős faktor az emberi tőke. Az emberi tőkét úgy definiálhatjuk, hogy az ember belső, személyétől elkülöníthetetlen adottságai, jellemvonásainak összessége, amelyre beruházás útján részesül és eredményeként növeli az egyén termelékenységét. A beruházás lehet egészségügyi célú költések (egészségfejlesztő programok), a kötelező oktatáson kívüli tanórák költségei és a legideálisabb munkahelyi állás megtalálásának időköltségeit is ide sorolhatjuk.

A vizsgálatom során szekunder adatgyüjtést hajtottam végre. Kutatásomban elsősorban az egészségfejlesztés és a fizikai aktivitással foglalkozó szakirodalmi forrásokat tekintettem át. A szakirodalmi források áttekintése után, a kutatás eredményeként összeségben elmondható, hogy az egészségfejlesztés és azon belül a fizikai aktivitásba történő beruházás elómozdítja az egészség javulását, valamint az életkereset és a munkatermelékenység növelését is.

Abstract. Today, workplace health promotion is increasingly present, both domestically and internationally. In my research, I used literature analysis to show how workplace health promotion programs, including physical activity, how affect employee earning capacity and productivity. Human capital is a significant factor in productivity. Human capital can be defined, that the human inner, inseparable features and characteristics of a person to which is invested and, as a result, increases the productivity of the individual. Investments can include health spending (health promotion programs), costs of extra-curricular lessons and time to find the ideal job.

I've been used secondary data collection during my research. In my research I have reviewed the source of literature on health promotion and physical activity primarily. After reviewing the literature, consequence of the research that investing in health, including investing in physical activity, it also contributes to improving health, as well as increasing life earnings and productivity at work. 


\section{Bevezetés}

Napjainkban a munkahelyi egészségfejlesztés egyre nagyobb mértékben van jelen, hazánkban és nemzetközi viszonylatban is. A munkahelyi egészségfejlesztést úgy definiálhatjuk, hogy a munkáltatók és a munkavállalók és maga a társadalom együttes erőfeszítései, a munkavállalók egészségének és jóllétének javítása érdekében. Az emberek jelentős idejét a munkahelyen töltik, ami által kevesebb idejük jut a különböző fizikai aktivitásokra, nehezen tudják megoldani az egészséges táplálkozást, és gyakran nem tudják magukat kipihenni (alvás hiány). A munkahelyi egészségfejlesztéseknek ezért kiemelten fontos szerepük van [3]. A munkahelyi egészségfejlesztő programok továbbá jelentősen befolyásolhatják a termelékenységet. A termelékenység esetében jelentős faktor az emberi tőke. Az elmúlt két évtizedben az emberi tôke és annak elemzése egyre inkább központi szerepet játszik a nemzetek és régiók gazdasági növekedésével kapcsolatos kérdéseiben. Ennek oka elsősorban az lehet, hogy a fejlett társadalmak egyre inkább a tudásalapú gazdaság felé tartanak [13]. Az emberi tőke több területen is fontos, beleértve a pszichológiát a mikro és makroökonómiát. Mikroökonómiai szinten az egyén készségeit, ismereteit, képességeit veszi figyelembe az emberi tőkével kapcsolatosan [5]. Az emberi tőke legfontosabb művei közé sorolható a közgazdasági Nobel emlék-díjas, Theodor W. Schultz, Beruházás emberi tőkébe (1961) című cikke, valamint a szintén közgazdasági Nobel emlék-díjas, Gary S. Becker, Emberi tőke (1964) című könyve. Az emberi tôke több fogalmi meghatározásban is jelen van az irodalomban. Az ember belső, személyétől elkülöníthetetlen adottságai, jellemvonásainak összessége, amelyre beruházás útján részesül és eredményeként növeli az egyén termelékenységét. Megfogalmazhatjuk úgy is, hogy a tőke definícióját kibővítjük az emberi erőforrásokra. Az emberi tőke kulcstényezői, hogy az egyéntől elkülöníthetetlen, beruházás folyamatán jön létre, fokozza a termelékenységet és a megemelkedett életkerestben térül meg [19]. Egy másik definíció szerint az emberi tőke az oktatás, tapasztalatok, képzés, intelligencia, munkahelyi szokások, amelyek befolyásolhatják a munkavállalók határtermékét [15]. Az emberi tőke elméletet úgy is megfogalmazhatjuk, hogy az adott egyén jövedelmét felhasználja-e a jelenben vagy annak bizonyos részét olyan javakra költi, amely által a jövőben nagyobb fogyasztást valósít meg. Az egyénen kívül, természetesen egy adott szervezet is beruházhat emberi tőkébe, ami a vizsgálatom szempontjából is fontos tényező. A szervezet emberi tőkébe történő beruházása azért történik meg, hogy saját jövőbeli hasznait gyarapítsa. Az emberi tőkébe több féle módon is beruházhatunk. Az emberi tőkébe történő beruházás magába foglalja az iskoláztatást, munkahelyi képzéseket, orvosi ellátást, amelyek fejlesztik a készségeket és az egészségi állapotot [5]. A beruházás lehet egészségügyi célú költségek, a kötelező oktatáson kívüli tanórák költségei és a legideálisabb munkahelyi állás megtalálásának időköltségeit is ide sorolhatjuk.

Az emberi tőke fogalmát először a 90-es évek elején terjesztették ki azzal, hogy az emberi tőkében az egészséget is fontos tényezőként kell kezelni, hiszen segíti az egyén tudásának és képességeinek fejlesztését [13]. Grossman (1972) tanulmányában egy olyan modellt állított fel, amelynek fókuszában az egészség, mint árucikk iránti keresletet mutatja be. A modell központi tényezője, hogy az egészség fenntartható tőkekészletnek tekinthető, aminek az egyén szempontjából az outputja az egészséges idő. A tanulmány feltételezése szerint az egyének olyan 
egészségügyi motívumokat örökölnek, amelyek az életkorral csökkenek, viszont ezek a tényezők beruházások által növelhetők, javíthatók. Az egészségügyi ellátásokra fordított összegek az életkorral együtt nőnek. A másik fontos tényező, hogy a fogyasztók egészségügyi és orvosi ellátás igényeinek pozitív kapcsolatban kell lenniük a bérükkel. Fontos faktor az egészség összefüggésében az árnyékár meghatározása. Az árnyékár abban az esetben merül fel, amikor egy szolgáltatás vagy termék nem rendelkezik hivatalosan megszabott árral. Az egészség árnyékára az orvosi ellátáson kívül egyéb tényezőktől is függ. Bizonyos feltételek mellett az árnyékár növekedése egy időben csökkentheti az igényelt egészég mennyiségét, valamint növelheti és növeli az igényelt orvosi ellátás mennyiségét [14].

\section{Szakirodalmi áttekintés}

Az egészség egyik alapfeltétele a fizikai aktivitás, azon belül is a sport. A sportos tevékenységek hozzájárulnak az emberi tőke és a munkavállalók készségeinek fejlesztéséhez. A sportolás befolyásolhatja a későbbi munkaerő-piaci sikereket. Az egyén termelékenysége függ az egészségi állapotától, amelyre közvetlen hatással van a fizikai aktivitás [8]. A sport eszköz lehet, hogy az adott egyént megtanítsa az együttműködésre, a csapatmunkára, elősegítheti a vezetői képességek kialakulását, valamint javíthatja az idő felhasználást is. A sporttal kapcsolatos tevékenységekben való részvételt, az egészséggel, fizikai megjelenéssel és az emberi tőkével hozták összefüggésbe. A sport és a testmozgás javíthatja az egyén fizikai és pszichés képességeit, amelyek közé a stressz kezelés, kitartás és a hatékonyabb csoportmunka tartozik. Az említett tényezők nem csak a termelékenységet teszik hatékonyabbá, hanem pozitívan befolyásolják a munkaerő-piaci szereplőket és az egyéni munkavállalói sikereket is [31]. Sahota és Sahota (1984) kutatásukban az emberi tőke beruházás, és a fizikai készségek elsajátításának folyamatát vizsgálták meg. A tanulmány fókuszában pedig az emberi tőke beruházáson belül az egészségügyi beruházások, míg a fizikai készségek elsajátításával kapcsolatosan, a sportba történő beruházás volt. Az egészségügyi beruházásokat két kategóriába sorolták:

1. betegségmentes, hosszú egészséges élet elérésére irányuló beruházás

2. a fizikai erőnlétbe és a különböző sporttevékenységek gyakorlásához szükséges tudásba való beruházás

Az emberi tőke beruházás a sport által, jelentheti az emberorientált menedzsment tevékenység fejlesztését és az emberi erőforrások minőségének javítását is. A befektetés ezen módja több kategóriába sorolható. Egyéni befektetés, szervezeti befektetés és kormányzati befektetés. Az emberi tőkebefektetés egyéni részében lehet a sport összefüggésében fizikai erőnlétbe, oktatásba valamint a sport technikai készségeinek elsajátításába. A szervezeti beruházás szintjén vannak a munkahelyi tréningek, munkaképzés és prevenciós programok. Kormányzati beruházás magában foglalja a testnevelés órák számának növelését a közoktatásban, pénzügyi támogatás a sporttevékenységek gyakorlásához, valamint az egészségügyi hozzájárulásokat lehet megemlíteni [22].

Az emberi tőkébe történő beruházást már gyermekkortól kezdve érdemes megtenni, hiszen a jövőben pozitív hatással lesznek az egyénre. Az emberi tőke növekedésének egyik kulcseleme a 
sport és a testmozgás [2]. Baliey (2013) kutatásában kialakított emberi tőke modell esetében a sportot állította középpontba. A sport és testmozgás, értéket teremt a jóllét, oktatási eredmények, valamint a gazdasági értékek révén. Az emberi tőke modell keretezi a fejlesztés folyamatában részt vevő tőke tényezőket. Ide sorolhatjuk azokat a tényezőket, amelyek egy egész élet során szükségesek az egyén fejlődésében. A legfontosabb faktorok a fizikai, érzelmi, társadalmi, egyéni, szellemi és pénzügyi erőforrások. A fizikai aktivitás, mint beruházás képes társadalmi szempontból értékes egyént kialakítani. A fizikai aktivitást úgy definiálhatjuk, hogy azok az ember által végrehajtott mozgásformák, amelyek plusz energia kifejtést igényelnek. Ide sorolhatjuk a kertészkedést, gyaloglást, és alapvetően a sporttal kapcsolatos tevékenységeket is [26].

A már korábban említett sporttal és testmozgással kapcsolatos tőke területeket részletesebben is kifejtem. A fizikai aktivitás, valamint az emberi fejlődés összefüggésében, hat különböző tőkét állapítottak meg [1]:

- Fizikai tőke

A sport és a fizikai aktivitás közvetlen előnyei, mint a testi egészség, prevenció, betegségek megelőzése, valamint a krónikus betegségek (szívbetegség, cukorbetegség) és az elhízás kialakulásának megelőzése.

- Érzelmi tőke

Ide sorolhatjuk a pszichológiai és mentális egészség előnyeit. Az egyén önértékelésének és önhatékonyágának pozitív irányba történő elmozdulása, a depresszió és a szorongás csökkentése, valamint a társadalmi elszigeteltség és a stresszes helyzetek hatékonyabb kezelésének kialakulása.

- Egyéni tőke

Az egyén karaktereinek elemei. Életkészségek, interperszonális készségek, értékek, amelyek a sport gyakorlása által pozitív irányban alakulhatnak ki az emberekben. Az egyéni tőke pozitív hatásaihoz sorolható a csapatmunka és a hatékonyabb együttműködés, az erkölcsi és társadalmi szempontok, mint a felelősség és a rugalmasság.

- Társadalmi tőke

A társadalmi tőke pozitív hatása abban mérhető, hogy az emberek, és csoportok közötti kapcsolatok erősödnek, annak eredményeként, hogy valamilyen közös sporttevékenységben vesznek részt. A tőke e területe magában foglalja a társadalmi befogadást, a fizikai aktivitás révén.

- Intellektuális (Szellemi) tőke

Az oktatási és kognitív fejlődés egyre inkább kapcsolható a sporthoz és a testmozgáshoz. A tőke jellemzője, hogy a rendszeres testmozgás hatásaira összpontosít, ami a kognitív működésről és az egyén iskolai teljesítményéről, valamint az általános tudományos eredményeiről ad visszajelzést.

- Pénzügyi tőke

A pénzügyi tőke esetében a keresőképesség, munkavégzés, munkahelyteremtés, valamint az egészségügyi költségek csökkentése (hiányzás, azaz alacsonyabb termelékenység) köthető a rendszeres testmozgáshoz. 
Humpreys és Münich (2008) megközelítése szerint a sportban való részvételt, az emberi tőke speciális formájának kell tekinteni. A sportolás folyamatát a sportspecifikus edzésnek nevezzük, amely mind szellemi, mind fizikai megterhelést igényel. A sportban szükségesnek tekinthető készségek elsajátításához, időt, erőfeszítést kell áldozni, oktatásban részt venni, valamint bizonyos szintű tapasztalatot kell, hogy szerezzen az egyén. A sportba történő befektetés irányulhat arra, hogy a befektetés célja a jobb egészségügyi állapot elérése. Az egyének sportban való részvételére több döntési tényezőtől függ. A sporttevékenységek gyakorlása számos haszonnal járhat, mint a jobb egészségügyi állapot, és a várható élettartamot is meghosszabbíthatja. A sportoláshoz szükséges készségek az emberi tőke speciális formája. A sporttevékenységek által a munkavállalók termelékenyebbek lesznek, aminek köszönhetően saját jövedelmük is magasabb lesz [17].

\section{Anyag és módszer}

A vizsgálatomban kiemelt szempontnak tartottam, hogy több olyan nemzetközi tanulmányt vizsgáljak meg, ami az emberi tőke és az egészségfejlesztés kapcsolatával foglalkozik. Témámban kifejezetten az egészségfejlesztés munkahelyi hatásait vizsgáltam, ezért arra fókuszáltam, hogy minél több olyan szakirodalmi forrást tárjak fel, ami kimondottan a munkahelyi egészségfejlesztést és annak munkaerő-piaci hatásait tárgyalja. Az egészségfejlesztés tekintetében pedig a fizikai aktivitással összefüggő szakirodalmi forrásokat részesítettem előnyben. Fontos megjegyezni, hogy a fizikai aktivitás mellett, az iskolai sport munkaerő-piaci hatásainak feltárása is kiemelt szerepet játszott a kutatásomban.

A kutatásomban szekunder adatgyűjtést alkalmaztam. A vizsgálatomban továbbá szakirodalmi elemzést hajtottam végre. Az elemzett szakirodalmi források legnagyobb arányban primer kutatások empirikus eredményeit foglalja össze. A kutatásban használt szakirodalmi források többségében fejlett országokban (magas jövedelmü országokban) végzett vizsgálatokon alapszanak.

\section{Eredmények}

Jelen fejezetben több olyan szakirodalmi forrás eredményeit mutatom be, ami az egészségfejlesztés emberi tőkére gyakorolt munkaerő-piaci hatásait mutatja be. A munkahelyi egészségfejlesztés mellett az iskolai sport által kifejtett munkaerő-piaci hatásokról is említést teszek.

Tapsin és Yazicin (2018) kutatásukban arra helyezték a hangsúlyt, hogy a sportolást minél hamarabb célszerű elkezdeni, ami több előnnyel is járhat a jövőben, ideértve a munkaerő-piaci sikereket. Azok a gyerekek, akik hamar kapcsolódnak az aktív sportba, több előnyt is szerezhetnek. A pozitív hatások közé sorolható, hogy 10\%-al csökken az elhízás esélye, míg a tanulmányi eredményeket illetően 40\%-al sikeresebb lehetnek. Kevesebb továbbá annak a kockázata, hogy a gyerekek káros szenvedélyek rabjai lesznek. Ami a munkaerő-piaci sikereket illeti, az aktív testmozgás által 7-8\%-al növekedhet az éves jövedelem, mivel a munkahelyen aktívabbak és ezáltal termelékenyebbek lesznek a munkavállalók. A kutatások szerint, azok a 
gyermekek, akik sportolnak, nagyobb arányban lesznek termelékenyebbek, mint akik nem sportoltak. Postalewaite és Silverman (2005) tanulmányukban a középiskolás sportprogramok pozitív hatását mutatták be vizsgálatukban. Eredményeik szerint azok a munkavállalók, akik középiskolai tanulmányuk során sportoltak, 26\%-al nagyobb jövedelemmel rendelkeznek, azoktól a társaiktól, akik nem sportoltak. Szintén középiskolások között végzett kutatások alapján határozták meg azt, hogy azok a munkavállalók, akik tanulmányaik során sportoltak, többet keresnek munkavállalóként azoknál a társaiknál, akik nem sportoltak a középiskolás éveik alatt. A sportolás továbbá növeli a termelékenységet is. Ennek összefüggésében a középiskolában végzett sporttevékenységek 4,2-14,8\%-al növelik a termelékenységet. A középiskolai adatok felhasználásával az eredmények azt mutatják, hogy azok akik sportoltak tanulmányaik során, pozitív hatással volt a későbbi tanulmányaikra és fontos tényezője a munkaerő-piaci sikereknek is[4].

Cabane és Clark (2015) kutatásukban azt az eredményt kapták, hogy azok a gyerekek akik egyéni sportokat folytattak, pozitívan korreláltak a jövőbeli szervezeti felelősségekkel, míg a csapatsportokban résztvevők esetében szorosabb kapcsolat volt az önállósággal. A fizikai aktivitás és sport jelzésként befolyásolhatja a munkaerő-piaci sikerek kialakulását. Ebben a megközelítésben a sport jelzéseket küld az egyén nem kognitív képességeiről.

Hallman et, al. (2011) tanulmányukban pozitív kapcsolat merült fel az emberi tőke és a sportban való részvétel között. Az oktatás kapcsán azt az eredményt kapták, hogy a felsőfokú végzettség és a sporttevékenységek között szintén pozitív korreláció merült fel. A felsőfokú végzetséggel rendelkező emberek nagyobb valószínűséggel sportolnak az alacsonyabb végzettséggel rendelkező társaiknál. Magyarázatként azt állapították meg, hogy a magasabban képzett egyének a jobb jövedelmi lehetôségeik miatt sportolnak többet. Long és Caudil (1991) kutatásukban azt az eredményt kapták, hogy azok a férfiak, akik végeztek sporttevékenységet felsőfokú tanulmányaik során, 4\%-al magasabb jövedelemmel rendelkeztek a munkaerőpiacon, mint akik nem sportoltak. A nők esetében szignifikáns különbség nem merült fel, ami a sporttevékenység és a jövedelem kapcsolatát illeti. A sportban való részvétel pozitív hatásait megfigyelhetjük a tanulmányi és munkaerő-piaci sikerekben egyaránt. A pozitív eredmények arra utalnak, hogy a sportolás elősegítheti a fegyelem, motiváció, bizalom és más szubjektív tulajdonságok fejlődését, amelyek ösztönzőleg hatnak a sikerre. Eide és Ronan (2001) eredményei alapján azt állapították meg, hogy a sportban való részvétel kapcsolatban van a munkaerő-piaci sikerrel és az egyén keresetével is. A kapcsolat fontos összefüggésre utal a testmozgás, emberi tőke és a termelékenység között. Az oktatás és az iskolai végzettség az emberi tőke fejlesztésének fontos tényezői. A másik releváns faktor az ifjúságfejlesztés. Az ifjúságfejlesztésre irányuló elképzelések, programok, gyakorlatok hozzájárulnak az emberi tőke fejlődéséhez, ami egy fenntartható fejlődési folyamatot alakít ki. A testmozgás és a sport közvetlenül növeli az egyén termelékenységét. Azok a volt középiskolások, akik sportoltak tanulmányaik során, nagyobb jövedelemmel rendelkeztek, mint akik nem sportoltak, valamint bizonyított tény, hogy a sporttevékenységek gyakorlása növeli a termelékenységet. Azok a munkavállalók, akik tanulmányaik során sportoltak, átlagosan jobb vezetői képeségekkel rendelkeznek, valamint jobb az önértékelésük és az önbecsülésük is, mint akik nem sportoltak. A sport továbbá befolyásolhatja a fontos készségek és értékek fejlődését is [20]. 
Lechner és Sari (2015) tanulmányukban egy idősoros vizsgálat alapján azt az eredményt kapták, hogy napi 38 perc fizikai aktivitás által 10\%-ról-20\%-ra nőtt a jövedelemszerzési hatás. A kutatásban a Leisure Time Physical Acitivity (LTPA) vagyis a szabadidős fizikai aktivitást vették alapul, ami a fizikai aktivitást szintjeit foglalja össze. A fizikai aktivitást inaktív, mérsékelten aktív és aktív szintekre osztották fel. Az inaktív alatt azt értjük, hogy azok az egyének, akik egyáltalán nem végeznek nagyobb intenzitású mozgásformákat, mint a súlyzós edzés vagy futás, de ettől függetlenül például alacsony tempójú sétát, kertészkedést végeznek. A mérsékelten aktív alatt, a napi 30 perces lassú sétát és a 20 perces közepes intenzitású sétálást értjük. A mérsékelten aktív célja a napi 30 perces séta. A WHO ajánlása szerint, a minden 18-65 év közötti felnőttnek hetente öt alkalommal közepes intenzitású aerob mozgást kell végezniük. A vizsgálat alapján viszont azt határozták meg, hogy a WHO ajánlott szinttől több mozgással, jobb eredményeket érhetünk el. Az aktív esetében a 30 perces sétálás mellé a napi 15 percnél rövidebb futást értjük, valamint a csapatsportokban való részvételt, ami lehet kosárlabda, röplabda, jégkorong, labdarúgás. Egyértelműen bizonyították azt az eredményt, miszerint a futás váltja ki a legnagyobb pozitív hatást. A vizsgálat továbbá kimutatta, hogy az 1998-2002-es időszakban végzett kísérletek alapján a mérsékelten aktívról aktívra történő változások a foglalkoztatást növelését idézte elő. Ez azt vonja maga után, hogy a sport és a testmozgás növeli a szabadidő értékét. Egy idő után a jól ütemezett, kialakított sport és testmozgásra vonatkozó beruházás növelheti az egyéni termelékenységet. A munkahelyi sportolás által a munkaidő értékesebb lesz, növekszik a foglalkoztatás a tevékenységi szinttel, hogy kihasználhassák az ebből adódó előnyöket. A szakirodalmi források leginkább az rövid távú hatásokat figyelték meg, miszerint az inaktívrólmérsékelten aktívra történő változás által már pozitív hatás figyelhető meg az egyén egészségi állapotára. Azonban a hosszú távú tényezőket is figyelembe véve, az említett változás nem elegendő, a tényleges pozitív hatás kialakulásához. Hosszú távon csak a mérsékelten aktívrólaktívra történő változásnak vannak szignifikánsan nagyobb pozitív hatásai az egészségre [21]. Lechner és Sari (2014), kanadai egészségügyi adatokat felhasználva azt az eredményt kapták, hogy az inaktívról mérsékelten aktívra történő változás már csökkentheti az egészségügyi ellátásokat, viszont amennyiben az aktív szintet éri el az egyén, annál nagyobb arányban csökkentheti az egészségügyi ellátások mértékét. A pontos eredmények szerint a korházban töltött idő száma 3541\%-al csökkenthető, Az inaktívról-aktívra történő változás, a nők és a krónikus betegségben szenvedő emberek esetében a hatás pozitív eredményei jobban megfigyelhetők. Az inaktív egyéneket tekintve, 12\%-al több ápolói, 5\%-al több háziorvosi és 13\%-al több egyéb orvosi szolgáltatást vesznek igénybe. A sporttevékenységek végzése és a testmozgás továbbá több pozitív hatással jár. Ide sorolhatjuk a jobb hangulat, egészségi állapot, fizikai erőnlét, a kognitív képességek és a nem kognitív képességek (önfegyelem, kitartás, önbizalom, csapatmunkában való közreműködés) fejlesztése [21]. Kavetsos (2011) szerint a testmozgásban aktívabb egyének, nagyobb eséllyel akarnak munkát vállalni azoknál, akik egyáltalán nem végeznek fizikai aktivitást. Fontos megjegyezni továbbá, hogy azok, akik rendszeresen végeznek fizikai aktivitást, nagyobb valószínűséggel találnak munkát is.

Rooth (2010) tanulmányában arra kereste a választ, hogy a fizikai erőnlét kapcsolatban lehet-e a munkaerő-piaci sikerekkel, valamint összefügésben lehet-e azzal, hogy nagyobb eséllyel hívnak vissza egy munkavállalót állásinterjú után. Ezzel összefüggésben lényeges tényező, hogy ennek alapján meghatározták milyen a jelzés értéke annak, hogy ha valaki sportol. Az eredmények 
szerint, 2\%-al nő az állásinterjúk visszahívási aránya, amennyiben az adott munkavállaló sporttevékenységet végez. A nehéz fizikai munkák esetében ez 5\%-al nagyobb arányt mutat, ami azzal magyarázható, hogy az effajta állásoknál fontosabb, hogy a munkavállaló jobb erőnléti állapotban legyen.

Meltzer és Jena (2010) kutatásukban azt állapították meg, hogy az intenzív testmozgás pozitívan kapcsolódik a bérekhez. A testmozgás által jobb lesz a munkavállaló egészségi állapota, ami a jövedelmére is hatással lehet. A jobb egészségi állapot, magasabb intenzitást és magasabb béreket idézhet elő. A testmozgásra fordított idő azt sugallja, hogy az edzésprogramokon való részvétel sikeresebb lehet, hogy ha az egyént ösztönzik a testmozgás fokozatos intenzitására, amivel egészégessebbé válhat. Általánosságában arra a következtetésre jutottak, hogy a hatékony fizikai aktivitás elsősorban a megfelelő intenzitású edzéseken múlik.

Dale et al (2019) tanulmányukban arra világítottak rá, hogy a nagyobb vállalatoknál több lehetőséget nyújtanak a munkahelyi egészségfejlesztésre, mint a kisebb vállalkozások esetében. Ennek ellenére azt az eredményt kapták továbbá, hogy a kis vállalkozásokat tekintve a munkavállalók nagyobb arányban vesznek részt az egészségfejlesztő programokon, mint a nagyobb vállalatok munkavállalói. A kutatásban továbbá azt állapították meg, hogy kisvállalkozások esetében nagyobb eséllyel támogatják ezeket a programokat, valamint a lebonyolítása is gördülékenyebb zajlik, mint egy nagyobb vállalatnál. A programok megvalósításában előnyt jelent, hogy a kisebb vállalkozásoknál jobban testre tudják szabni a programokat, kevésbé bürokratikus a szervezés, hiszen a menedzsment több teret kap, valamint nagyobb lehet az együttmúködés és a csapatmunka egy kisebb vállalkozásban. Az egészségfejlesztésben való részvétel a jövedelemtől is függ. A nagyobb jövedelemmel rendelkező munkavállalók többször vettek részt az egészségfejlesztő programokban. A munkahelyi egészségfejlesztő programok és tevékenységek iparáganként is változó trendet mutatnak. A programokhoz a legtöbb támogatás az oktatás, és az egészségügy területén figyelhető meg. A legkevesebb törekvés pedig a kereskedelemben, szolgáltatóiparban, és az élelmiszeriparban lelhető fel.

Az egészségfejlesztési programok több pozitív gazdasági hatással járnak. Ide sorolhatjuk a hiányzások arányának, munkavállalók egészségügyi költségeinek, valamint a munkavállalók fluktuációjának csökkentését [12]. Etemadi et, al. (2016) tanulmányuk eredményei alapján kiderült, hogy a fizikai aktivitás és a termelékenység közvetlen kapcsolatban van. A kutatás alanyai (tőzsdeügynökök, ingatlan kereskedők) részt vettek egy 12 hétig tartó aerobik programban. A program után azt az eredményt kapták, hogy magasabb eladási szintet tudtak produkálni, azon társaikhoz képest, akik nem vettek részt a programban. A vizsgálat után azt is megfigyelték, hogy a programban résztvevő munkavállalók nagyobb önbizalommal és koncentrációval végezték a munkájukat. Az egészségfejlesztő programok a stressz kezelés egyik kulcseleme, hiszen a testmozgás csökkentheti a stressz és a depresszió tüneteit. A megfelelő egészségfejlesztő programok kialakításához, szükséges a tanácsadás, edzőteremben végeztett rekreációs mozgás. A testmozgás fontos tényező az egészségügyi költségek csökkentése szempontjából. Az egészségfejlesztő programok pozitívan befolyásolják termelékenységet [12]. Dunnagan et, al. (1999) egyetemi dolgozók körében végzett kutatásukban, a munkahelyi wellness és fitness programok lebonyolításával vizsgálták meg a fizikai aktivitás hatását az egészségi 
állapotra és arra, hogy ezzel csökkenteni lehet-e az egészségügyi költségeket. A programok között szerepelt az alacsony intenzitású aerobik mozgás, a stepaerobik, a nyújtás és a hajlítás, valamint a vízi aerobik. A másik részben lehetőségük volt, az edzőteremben súlyzós edzésekben részt venni. A programot úgy bonyolították le, hogy a munkavállalók munka elött és munka után is elvégezhették a választott mozgásformákat. Az eredmények alapján azt állapították meg, hogy a wellness programok pozitívan hatnak az egyén egészségügyi állapotára és az effajta fizikai aktivitással csökkenteni lehet az egészségügyi költségeket is.

Seaton et, al (2017) kutatásukban kanadai példa alapján vizsgálták meg a munkahelyi egészségfejlesztést hatásait. A vizsgált egészségfejlesztő program neve a POWERPLAY volt. A kezdeményezés férfi munkavállalók felé irányult. A POWERPLAY programban három szállítmányozó cég és egy regionális önkormányzat vett részt. A program két, hat hetes periódusból állt, amelyben különböző foglalkozások, kihívások, valamint versenyek szerepeltek. Az egészségfejlesztő programban szerepelt az egészséges étrend beillesztése az étkeztetésbe, egészségügyi szűrések (tanácsadás szakemberektől), illetve fizikai aktivitáshoz köthető testmozgások (jégkorong). Az egészségfejlesztés keretein belül egy információs könyvet is adtak a munkavállalóknak, amelyben a kihívás részletei szerepeltek, többek között az egészséges étrend és a fizikai aktivitás jótékony hatásainak részletes tájékoztatása. A program megvalósításával kapcsolatban azt a következtetést vonták le, hogy hosszú távon elősegítheti a munkavállalók egészségi állapotának folyamatos javítását és egy hatékony modell lehet a férfiak egészségének javítása érdekében.

\section{Következtetések}

Az egyre inkább modernebb munkahelyek és munkakörök miatt az emberi tőke beruházásra nagyobb hangsúlyt kell fektetniük a vállalatoknak és a munkavállalóknak egyaránt. Az emberi tőke fejlesztése által a munkavállalók növelhetik munkatermelékenységüket és életkeresetüket is. Fontos megjegyezni, hogy a vállalatoknak is lényeges szempont az emberi tőkébe történő beruházás, hiszen ezáltal jelentős mértékben gyarapíthatja jövőbeli hasznait.

Kutatásomban az emberi tőke beruházás egyik lehetséges opciójára, az egészségfejlesztésre azon belül a fizikai aktivitás pozitív munkaerő-piaci hatásaira fókuszáltam. A szakirodalmi források eredményei alapján az figyelhető meg, hogy az egészségfejlesztés és a fizikai aktivitás, jelentős mértékben befolyásolja a munkaerő-piaci sikereket. A fizikai aktivitás által több pozitív eredmény érhető el, vállalati és egyéni szinten is. A legfontosabb eredmények a termelékenység fokozása, jövedelem növelő hatása, egészségügyi költségek és hiányzások csökkentése, valamint a fluktuáció redukálása.

Összeségében megállapítható, hogy a fizikai aktivitásba történő beruházás, minőségi és mennyiségi szempontból is értékes beruházást jelent (egészségi helyzet javulása, életkereset növelése, munkatermelékenység fokozása) [1].

\section{Köszönetnyilvánítás}


„A publikáció élkészítését az EFOP-3.6.1-16-2016-00022 számú, Debrecen Venture Catapult Program című projekt támogatta. A projekt az Európai Unió támogatásával, az Európai Szociális Alap társfinanszírozásával valósult még."

\section{Hivatkozások}

[1] Bailey, R. -Cope, E. -Parnell, D. (2015): Realising the Benefits of Sports and Physical Activity: The Human Capital Model. Retos. Vol. 28. pp. 147-154.

[2] Bailey, R. - Hillman, C. - Arent, S. -Petitpas, A. (2013): Physical Activity: An Underestimated Investment in Human Capital? Journal of Physical Activity and Health, Vol.10. pp. 289-309.

[3] Banwell, C. -Sargent, G. - Dixon, J. - Strazdins, L. (2017): A cultural economy approach to workplace health promotion in Australian small and medium sized workplaces: a critical qualitative study. Critical Public Health. pp. 1-10.

[4] Barron, J. - Ewing, T. - Waddel, G. (2000): The effects of high school athletic participation on education and labor market outcomes. Review of Economics and Statistics. Vol.82, No. 3. pp. 409-421.

[5] Becker, G., S., (1975): Human Capital. National Bureau of Economic Research. ISBN: 0870145134

[6] Boon, C.- Eckdart, R. - Lepak, D. -Boselle, P. (2017): Integrating strategic human capital and strategic human resource management. The International Journal of Human Resource Management, Vol. 29, No.1, pp. 34-67.

[7] Cabane, C. - Clark, E. (2015): Childhood Sporting Activities and Adult Labour-Market Outcomes. Annals of Economics and Statistics. No. 119-120. pp. 123-148.

[8] Cabane C. - Lechner, M. (2014): Physical activity of adults: A survey of correlates, determinants, and effects. ZEW Discussion Papers, No. 14-088, pp. 1-49.

[9] Dale, A. - Enke C. -Petty, S. -Hipp, A. - Marx, C. - Strickland, J. - Evanoff, B. (2019): Availability and Use of Workplace Supports for Health Promotion among Employees of Small and Large Businesses. American Journal of Health Promotion. pp.1-18.

[10] Dunnagan, T. - Haynes, G. - Noland, M. (1999): Health Care Costs and Participation in Fitness Programming. American Journal Of Health Behavior. Vol.23., No.1, pp.43-51.

[11] Eide, E. - Ronan, N. (2001): Is participation in high school athletics an investment or a consumption good? Evidence from high school and beyond. Economics of Education Review. Vol. 20. pp.431-442.

[12] Etemadi, M. -Shameli K. - Hassan, N. - Zakaria, Z. - Khatrudin, A. - Hara, H. (2016): A Review of the Importance of Physical Fitness to Company Performance and Productivity. American Journal of Applied Sciences. Vol 13. No.11. pp. 1104-1118. 
[13] Faggien, A. - McCann, P. (2009): Human capital and regional development. In, Capello, R. - Nijkamp, P. Handbook of Regional Growth and Development Theories. Cheltenham, UK. Edward Elgar, pp. 131-151.

[14] Grossman, M. (1972): On the Concept of Health Capital and the Demand for Health. Journal of Political Economy. Vol. 80, No.2. pp. 223-255.

[15] Frank, R. H.- Bernanke, B. S. (2007). Principles of Microeconomics. New York: McGrawHill/Irwin

[16] Hallman, K. - Wicker, P. - Breuer, C. - Schütoff, U. (2011): Interdependency of sport supply and sport demand in German metropolitan and mediumsized municipalities - findings from multi-level analyses. European Journal for Sport and Society. Vol. 8, No.1, pp. 65-84.

[17] Humphreys, B. - Munich, D. (2008). Sport Participation and Migration. International Journal of Sport Management and Marketing, Vol.3, No. 4, pp. 335-347.

[18] Kavetsos, G. (2011). The Impact of Physical Activity on Employment, The Journal of SocioEconomics, 40, 775-779.

[19] Kun, A., (2009): Az oktatási sorting elmélet és empirikus tesztelésének problémái. PhD Értekezés, Debreceni Egyetem, Közgazdaságtudományi Doktori Iskola. p. 272.

[20] Lawson, H. (2005): Empowering people, facilitating community development, and contributing to sustainable development: The social work of sport, exercise, and physical education programs. Sport, Education and Society. Vol. 10, No. 1. pp. 135-160.

[21] Lechner, M . -Sari, N. (2015): Labor market effects of sports and exercise: Evidence from Canadian panel data. Labor Economics. Vol. 35. pp.1-15.

[22] Liu, K. (2015): Research of Investment in Human Capital in a Sports Club. International Journal of Simulation -- Systems, Science \& Technology . 2015, Vol. 16 Issue. pp.1-19.

[23] Long, J. - Caudill, S. (1991): The Impact of Participation in Intercollegiate Athletics on Income and Graduation. The Review of Economics and Statistics. Vol. 73, No.3. pp. 525531.

[24] Meltzer, D. - Jena, A. (2010): The economics of intense exercise. Labor Economics. Vol.29. pp. 347-352.

[25] Postlewaite, A. - Silverman, D. (2005): Social isolation and inequality. Journal of Economic Inequality. Vol.3. pp. 243-262.

[26] Pfau, C.- Pető, K. - Bácsné, Bába, É. (2019): A fizikai aktivitás, mint egészségbefektetés. Egészségfejlesztés. 9. évf. 1.sz. pp. 31-44.

[27] Rooth, D.- O. (2010): Work out or out of work - The labor market return to physical fitness and leisure sports activities. Labour Economics. Vol. 18. pp. 399-409.

[28] Sahota, C. - Sahota, K. (1984): A Theory of Human Investment in Physical Skills and Its Application to Achievement inTennis. Southern Economic Journal, Vol. 50, No. 3. pp. 642664

[29] Sari, N. (2009): Physical inactivity and its impact on healthcare utilization. Health Economics. Vol.18. pp. 885-901. 
[30] Seaton, C. - Bottorff, J. - Oliffe, J. -Johns-Bricker, M. -Caperchione, C. -Jonhson, S. - Sharp, P. (2017): Acceptability of the POWERPLAY Program: A Workplace Health Promotion Intervention for Men. American Journal of Men's Health. Vol. 11 No. 6. pp. 1809-1822.

[31] Tapsin, G. - Yazici, E. (2018): Sport Participation Rate And Labor Market Outcomes. Journal Of Humanities And Social Science. Vol. 23, No.4. pp.16-23. 